\title{
Spatial Organisation Influences Citrus Pseudocercospora Leaf and Fruit Spot Disease Severity in Cocoa-Based Agroforestry Systems
}

\author{
Eunice Golda Danièle Ndo ${ }^{{ }^{*}}$, Etienne Akoutou Mvondo',2, Zachée Ambang², Bella Manga1, \\ Christian Cilas ${ }^{3}$, Lucien Bidzanga Nomo', Cynthia Gidoin"4, Marie-Ange Ngo Bieng,6
}

${ }^{1}$ Institute of Agricultural Research for Development (IRAD), Regional Agricultural Research Centre of Nkolbisson, Nkolbisson, Cameroon

${ }^{2}$ Université de Yaoundé 1, Département de Biologie et Physiologie Végétale, Yaoundé, Cameroon

${ }^{3}$ CIRAD, UPR Bioagresseurs, Montpellier, France

${ }^{4}$ UMR Agronomie, INRA-AgroParisTech, Thiverval-Grignon, France

${ }^{5}$ CIRAD, UMR SYSTEM, Montpellier, France

${ }^{6}$ CATIE, Programa BOSQUES, BIODIVERSIDAD YCAMBIO CLIMATICO, Turrialba, Costa Rica

Email: ^lbidzanganomo@yahoo.fr

How to cite this paper: Ndo, E.G.D., Mvondo, E.A., Ambang, Z., Manga, B., Cilas, C., Nomo, L.B., Gidoin, C. and Bieng, M.-A.N. (2019) Spatial Organisation Influences Citrus Pseudocercospora Leaf and Fruit Spot Disease Severity in Cocoa-Based Agroforestry Systems. American Journal of Plant Sciences, 10, 221-235. https://doi.org/10.4236/ajps.2019.101017

Received: November 21, 2018

Accepted: January 22, 2019

Published: January 25, 2019

Copyright $\odot 2019$ by author(s) and Scientific Research Publishing Inc. This work is licensed under the Creative Commons Attribution International License (CC BY 4.0).

http://creativecommons.org/licenses/by/4.0/

(c) (7) Open Access

\begin{abstract}
An investigation to assess the spatial structure and severity of Pseudocercospora leaf and fruit spot disease (PLFSD) on citrus trees in cocoa-based agroforests was carried out in three contrasting ecological zones in southern Cameroon, viz: 1) the humid forest zone, 2) the degraded forest zone, and 3) the forest-savannah transition zone. Two main parameters were investigated viz: 1) the spatial structure of cocoa based agroforests, and 2) the disease severity. In total, the spatial structure of 19 cocoa-based agroforests was analysed using the Ripley $\mathrm{K}(\mathrm{r})$ function, meanwhile the collection of epidemiological data that consisted of noting the presence of PLFSD spots on leaves and fruits on 438 citrus trees was used to characterise the severity of the disease. Results showed that, the spatial structure of citrus trees in these agroforests investigated were regular in seven plots, random in nine, and aggregated in three. Aggregated plots presented a significantly higher mean of disease severity on leaves and fruits (28.55 and 30.37 respectively), as compared to randomised (20.91 and 16.32 respectively) and regular plots (16.28 and 14.97 respectively), at $\mathrm{P}$-value $<0.05$. These results suggest that the spatial structure of citrus trees in the cocoa-based agroforests studied influences the severity of PFLSD. Proper integrated control measures can therefore be initiated, leading to a considerable reduction of the use of manufactured inputs, and thereby, the cost of production of citrus fruits.
\end{abstract}




\section{Keywords}

Aggregated Spatial Structure, Ripley Function, Agroecological Management of Disease, Pseudocercospora angolensis, Cocoa-Based Agroforests, Citrus

\section{Introduction}

Spatial structure represents the structure of individual plants in space. It therefore reflects the local environment around each individual in plant community [1]. The local environment has an influence on the epidemiology of the pathogen when individual host of a pathogen is concerned. The local environment around a host plant can have an impact on the pathogens at different levels of their biological cycle. Diverse mechanisms are involved, including the presence of auxiliary fauna or flora favoured by complex spatial structures, pathogen dispersal (barrier effects, connectivity between host individuals in the plot), the contamination success of host organs, the progress of the infectious stages following microclimatic alterations determining pathogen development and plant host physiology [2].

Previous studies [3] [4] have established a link between spatial structure of shade trees (non-host in the canopy) and the incidence of pest and disease for the understory crop (hosts) in complex agroforest systems. Thus, the spatial arrangement of individual plants has an influence on the progression of disease, because it can act on the patho-system in two ways: 1) through its impact on the mechanism of reduction of the pathogen resource by influencing its movement, and 2) through its action on the micro-climate. Interactions between spatial structure of host plants on the one hand, and incidence of a given pathogen on the other hand are investigated, as identifying of these may give way to an ecological regulation of pest and disease, through an optimization of the spatial structure host plants during plantation and management action.

This study is also applied to the regulation of citrus Pseudocercospora leaf and fruit spot disease (PLFSD). PLFSD is a fungal disease due to Pseudocercospora angolensis (Carvalho \& Mendes; Crous \& U. Braun). Since 1952, this pathogen is a major limiting factor to Citrus spp. production in some 23 African countries and Yemen [5] [6] [7]. Because of traditional trade of plant material in these countries and the wind-borne nature of the fungal spores, this disease constitutes a potential threat [8]. The disease attacks leaves, fruits and young twigs causing many spots resulting in premature abscission and dieback [9]. Symptoms on leaves and fruits are showed on Figure 1. The damage due PLFSD on citrus in Cameroon and other African countries causes heavy crop loss and sorting deviations of up to $(50-100) \%$ of production on susceptible varieties, in areas of high disease incidence [10] [11] [12].

Improving the knowledge on factors influencing PLFSD development and severity is a subject of particular importance. Indeed, factors influencing the 

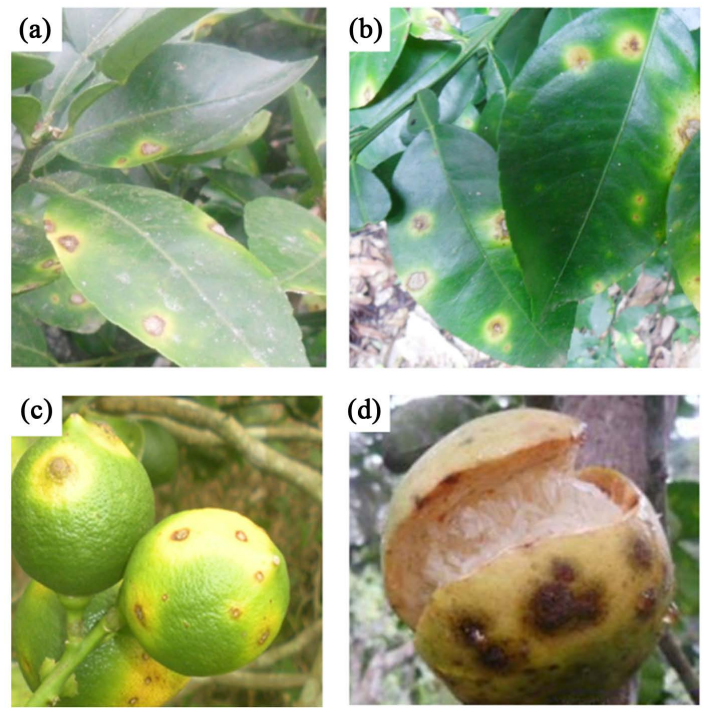

Figure 1. Leaf spots ((a), (b)) and fruit spots ((c), (d) caused by Pseudocercospora angolensis on citrus.

dynamics of this pathogen are scarce. The works undertaken have elucidated some factors associated with the development of the disease [7]. It is known that, low temperatures (high altitude) promote the development of the disease [11] [13]. In addition, species such as grape fruit, orange tree and some tangerine trees are very sensitive to PLFSD [14]. It is also known that conidia of $P$. angolensis are disseminated at short distance by wind or rain [15]. It has been demonstrated that when the distance between neighbouring citrus trees is greater than or equal to $12 \mathrm{~m}, P$. angolensis is difficult to spread from one tree to another [16].

In pure citrus orchards, where the distance between citrus trees is generally less or equal to $10 \mathrm{~m}$, the pathogen is easily spread. However, when citrus trees are associated with other species, the distance between citrus trees is usually greater and neighbour trees are not generally host plants or could be less sensitive. The dissemination of conidia is therefore difficult and the evolution of the epidemic can be contained. Plant biodiversity of agroforestry systems can therefore help to dilute the pathogen resource and thus to reduce its presence and damages [17].

In Cameroon, citrus trees are mostly grown in such systems, generally coffee or cocoa based agroforestry systems. These are complex systems with high biodiversity [18]. Within these systems, different citrus species are grown (oranges, grapefruits, lemons, tangerines, pomelos...) [19]. Spatial structure of citrus trees varies from one farm to another according to farmer's circumstances. From the different host species and the variety of spatial structure found in cocoa based agroforestry systems in Cameroon [4], we expected an interaction between spatial structure of host trees (citrus trees) and the disease severity [20].

The aim of this paper is to identify the interactions between the spatial structure of citrus trees in cocoa-based agroforests and the PLFSD severity. Analysis 
of factors influencing this under each particular spatial structure scenario is made. Based on the knowledge on the pathogen epidemiology, the mechanisms underpinning interactions are discussed. Management actions for optimal spatial structures of citrus within cocoa-based agroforest are proposed.

\section{Material and Methods}

\subsection{Study Zones and Sampling Plots}

The study was conducted in three zones situated in the southern Cameroon viz: 1) the evergreen humid forest zone, with monomodal rainfall patterns, mean annual temperatures of $22^{\circ} \mathrm{C}-29^{\circ} \mathrm{C}$ and a relative humidity of $85 \%-95 \%, 2$ ) the degraded humid forest zone with a bimodal rainfall patterns, and a mean annual temperature of $25^{\circ} \mathrm{C}$ and relative humidity of $75 \%$, and 3) the forest-savannah transition zone with a bimodal rainfall patterns, and a mean annual temperature of $27^{\circ} \mathrm{C}$ and relative humidity of $70 \%$.

The selection of studied areas and fields was based on: 1) the overall production of citrus in the area, 2) the diversity of associated perennial species within field, and 3) the number of citrus trees within field. A total network of 19 cocoa fields in the three studied areas viz: six (6) in the evergreen humid forest, five (5) in the degraded humid forest, and height (8) in the forest-savannah transition was therefore selected (Figure 2). Within each field, a plot of $2500 \mathrm{~m}^{2}$ comprising at least 12 citrus trees (all species) was set up. Perennial associated species within plot were inventoried to characterise the species composition, and to determine the sub-populations, as a mean to evaluate the biodiversity in each field.

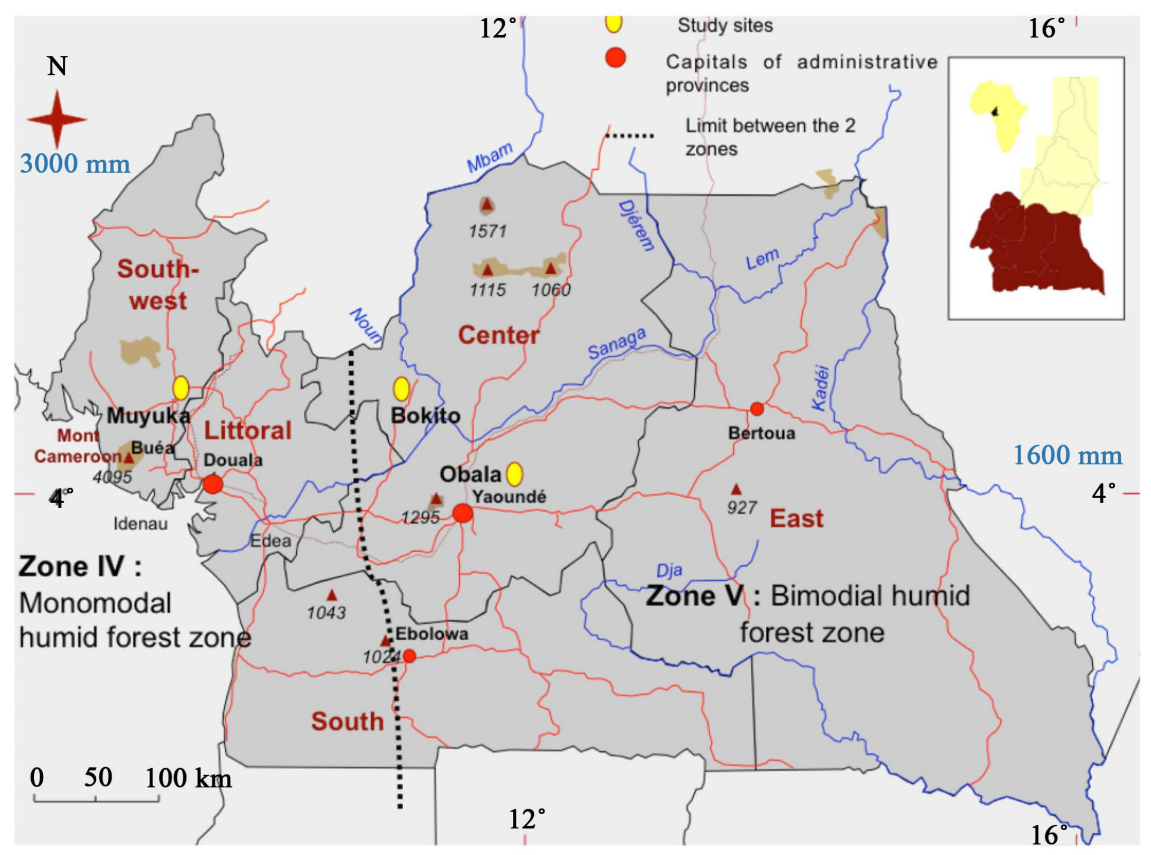

Figure 2. Location of the study sites in two agroecological humid zones of Cameroon. The study sites are Muyuka (monomodal humid forest zone), Bokito, and Obala (bimodal humid forest zone). 


\subsection{Characterization of Associated Species and Spatial Structure}

In order to characterize the spatial structure and the associated perennial species composition in each of the sample plot, the $\mathrm{X}$ and $\mathrm{Y}$ Cartesian coordinates of each perennial plant ( $\geq 2 \mathrm{~m}$ tall) were recorded [1], using measuring tape in each bordered plot. For each perennial found within plot, the species or family was identified. The perennials recorded were further grouped into five subpopulations: cocoa trees, forest trees, other fruit trees (except citrus), citrus trees and palm oil.

The major issue to address was the spatial structure of citrus trees, as it represents the host of the studied disease, but also because of statistical reasons, as the minimum targeted number of citrus trees was reached in the 19 selected plots. Contrary to the other subpopulations, cocoa trees which are the main crop, were obviously significantly represented. The study being conducted in farmers' fields, most citrus fruits are seedlings, only few trees are grafted on Citrus volcameriana, the majority of grafted trees were found in the Evergreen humid forest zone.

\subsection{Spatial Structure Analysis}

One of the aims of this paper was to highlight a possible correlation between a particular spatial type and a particular disease severity. Following the method illustrated in [1], we built a typology of spatial structure based on the spatial structure of the citrus trees in the study plots. In a first step, we characterized the horizontal spatial structure on the citrus trees in each plot using the $L(r)$ modified Ripley function $(K(r))$ [21]. The $L(r)$ function is based on the calculation of the expected number of neighbour trees within a distance $(r) \leq$ to $r$ of any point of the study pattern. The study pattern in this case is the set of citrus trees in each of the studied plot.

$$
L(r)=\sqrt{\frac{K(r)}{\pi}}-r
$$

This method enables to distinguish three types of tree spatial patterns: regular when $L(r)$ is $<0$, aggregated when $L(r)$ is $>0$, and random when $L(r)=0$.

In a second step, we performed a hierarchical cluster analysis based on the Euclidean distance between the values of the $L(r)$ function of the citrus trees in the different plots. It resulted in clusters of plots with a similar spatial structure, based on their trend to regular, random or aggregated spatial structure. This spatial analysis was done with ads package $\mathrm{R}$ 3.2.2 software

\subsection{Disease Severity and Analysis}

The disease severity was assessed, based on visual appreciation of disease symptoms on fruits and on leaves. Disease severity on leaves and fruits was evaluated by noting the presence of spots on these organs. On each tree, 10 new flushes (which are more sensitive to the disease) distributed on diverse branches of the tree were selected, and on each flush 8 leaves were observed. A total of 80 leaves 
were observed per tree. Concerning fruits, all the fruits present on each sampled tree were observed, and a fruit marked with at least one spot was considered as a lost fruit. The percentage of leaves and fruits marked by at least one disease spot was calculated per tree and represented severity index.

Severity index were log transformed in order to respect the normal distribution assumption. The variations in disease severity between the different types of spatial structure and between the three study zones were compared. The ANOVA was used to detect the level of differences between the mean of severity index of different plots according to their spatial organisation type. A comparison of means was done later using the Turkey test. The ade 4, ads and R-Commander Packages of the R 3.2.2 software were used to perform these analyses.

\section{Results}

\subsection{Composition of Citrus Subpopulation among the Plots}

Four citrus species namely: orange ( $C$. sinensis (L.)), tangerine ( $C$. Reticulata Blanco), grapefruit (C. paradisi (Macf.)) and lemon trees (C. Lemon (L.) Burm) were found in the study plots. Orange trees were the predominant specie among citrus; it was the most representative citrus tree in evergreen humid forest zoneand forest-savannah transition zone with percentages of $93.10 \%$ and $73.33 \%$ respectively. Tangerines were predominant in degraded humid forest zone with a proportion of $58.20 \%$. In Forest-savannah transition zone, that proportion was $23.13 \%$. Grapefruits were absent in evergreen humid forest zone and very little were represented in degraded humid forest zone and Forest-savannah transition zone $(8.95 \%$ and $3.13 \%$ respectively). In general, the citrus trees were significantly present in the three study zones (Figure 3 ).

\subsection{Typology of Spatial Structure of Citrus Trees in the Study Plots}

Analysis of the spatial structure of citrus trees was performed with Ripley function and highlighted a variety of spatial structure of citrus trees in the 19 studied

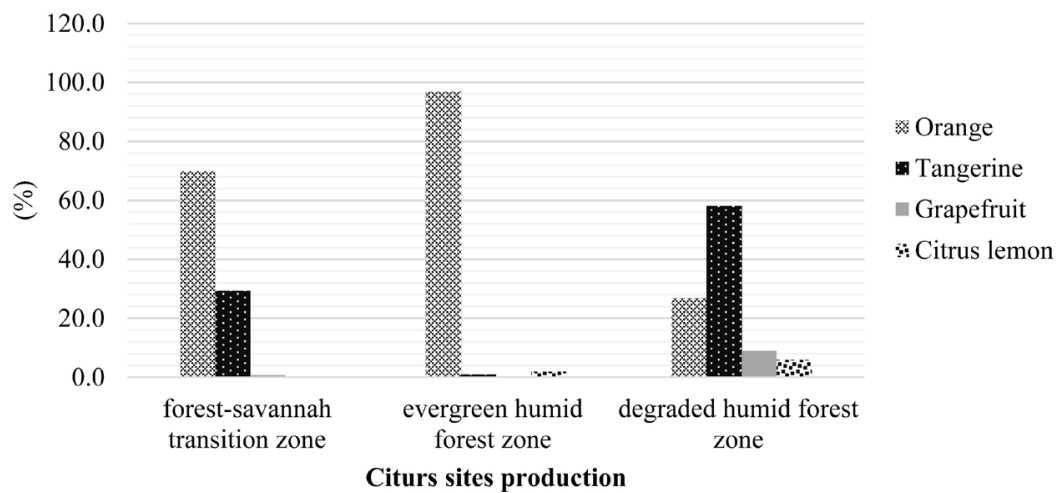

Figure 3. Percentage of citrus trees (Orange, tangerine, grape fruit and lemon trees) in the three cocoa agroforestry study zones. 
plots. The variety of spatial structure are represented in a dendrogram, results of the hierarchical cluster analysis based on the Euclidean distance between the values of the $L(r)$ function of the citrus trees in the different plots. The dendrogram identifies three main groups: the first with a regular spatial structure, the second with a random spatial structure, and the third with an aggregated spatial structure (Figure 4).

The dendrogram shows that:

- Citrus trees in seven plots were classified within the regular spatial structure group. In this group, five plots displayed a significant regular structure with negative values of the $L(r)$ function < the $95 \%$ confidence envelope for at least one $\mathrm{r}$ value, whereas two other plots ( 8 and 19), a trend towards a regular distribution was observed. The plot 6 (Figure 5(a)) illustrates this spatial structure, where the citrus trees are regularly distributed within the plot. The correspondent $L(r)$ function (Figure 5(b)) highlighted significant negative values with a peak at $5 \mathrm{~m}$, meaning that the trees are at a regular mean distance of $5 \mathrm{~m}$ between each other.

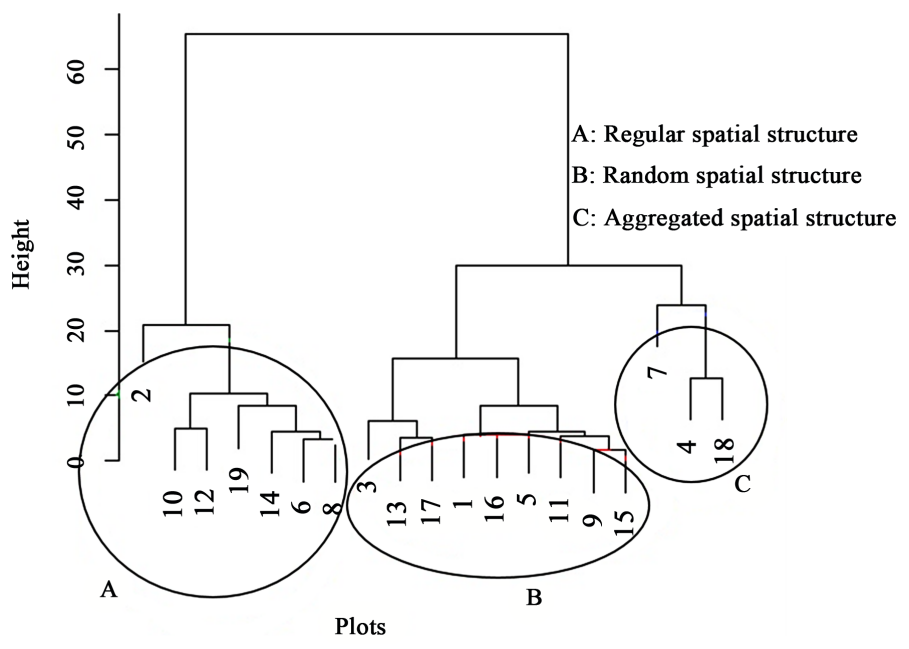

Figure 4. Representation of the hierarchical cluster analysis set up to characterize the different spatial structure of citrus trees in the 19 cocoa agroforestry plots.

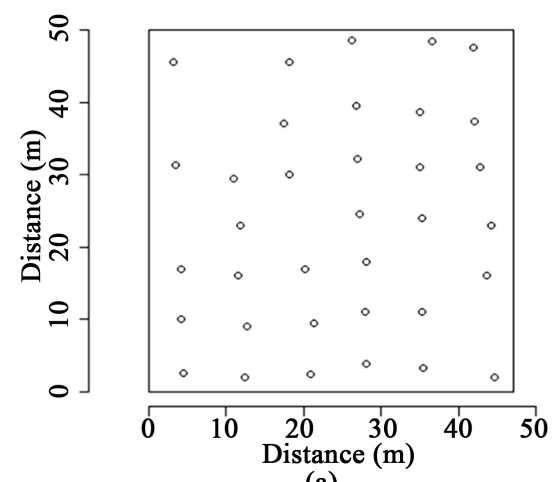

(a)

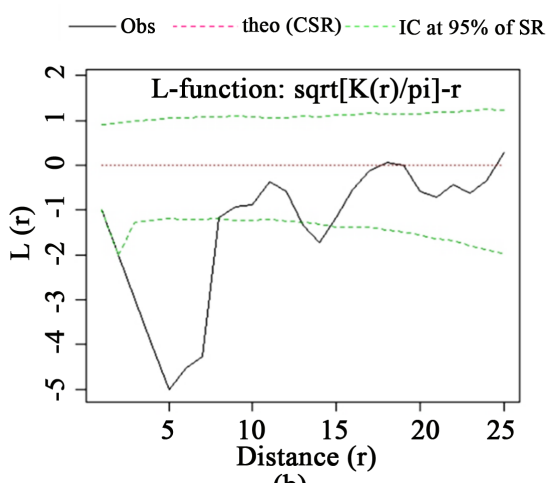

(b)

Figure 5. (a) Map of the citrus trees in the study plot 6 which presents a regular spatial structure and (b) its corresponding $L(\mathrm{r})$ function 
- Citrus trees in nine plots displayed a random spatial structure. The plot 5 (Figure 6(a)) illustrates this, where citrus trees are randomly distributed within the plot. The correspondent $L(r)$ function (Figure 6(b)) highlighted significant $L(r)$ values within the confidence interval, meaning that for the spatial structure of the citrus trees in this plot we cannot reject the null hypothesis.

- Citrus trees in three plots displayed a significant aggregated structure with positive values of the $L(r)$ function > the $95 \%$ confidence envelope for at least one $r$ value structure. The plot 7 (Figure 7(a)) illustrates this spatial structure, where the citrus trees are aggregated within the area of the plot. The correspondent $L(r)$ function (Figure $7(\mathrm{~b})$ ) highlighted significant positive values with a peak at $8 \mathrm{~m}$, meaning that the trees are aggregated in cluster with a mean radius of $8 \mathrm{~m}$.

\subsection{Severity of Disease within the Three Groups of Spatial Structure}

As highlighted in Table 1, there is a significant difference in disease severity between the three groups of spatial structure, concerning the severity on leaves as well as the one on fruits. In both cases, plots with Citrus trees in an aggregated

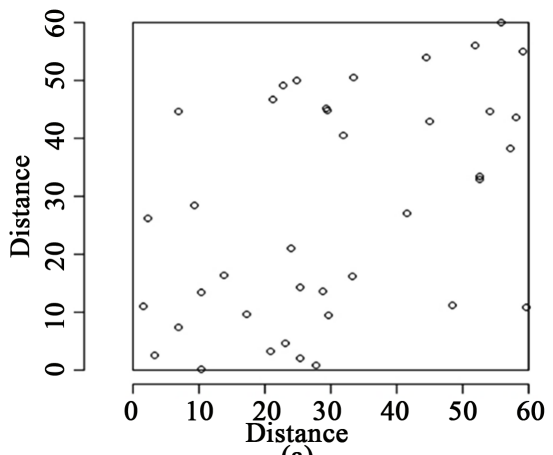

(a)

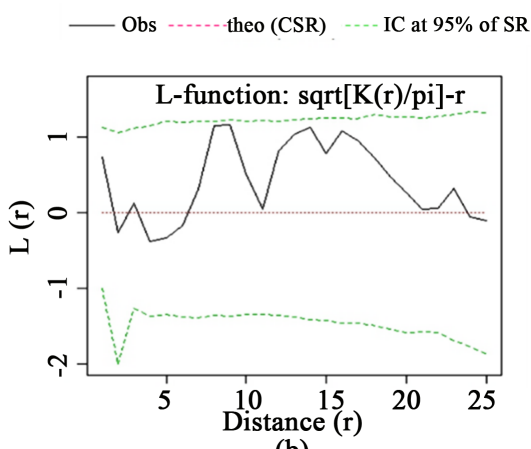

(b)

Figure 6. (a) Map of the citrus trees in the study plot 5 which presents a random spatial structure and (b) its corresponding $L(\mathrm{r})$ function

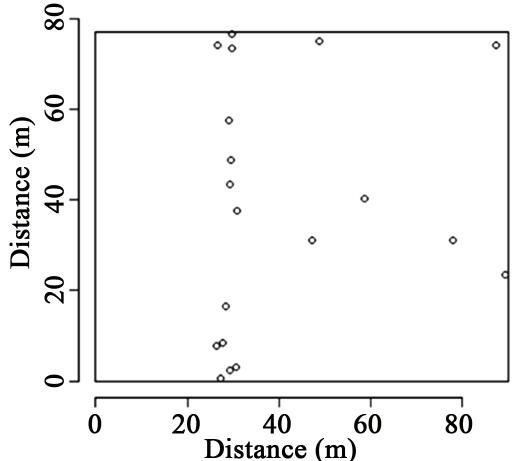

(a)

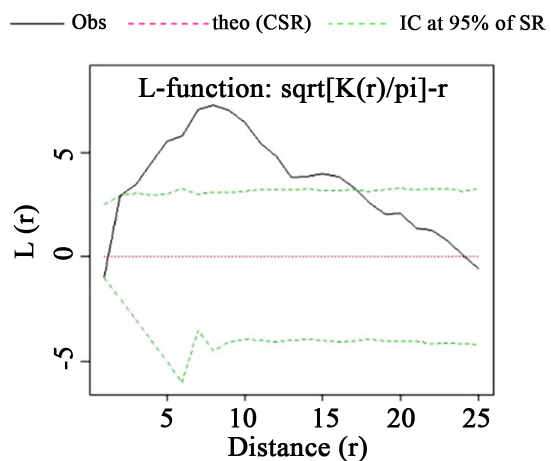

(b)

Figure 7. (a) Map of the citrus trees in the study plot 7, which presents an aggregated spatial structure and (b) its corresponding $L(\mathrm{r})$ function 
Table 1. Result of ANOVA performed on the PLFSD incidence to determine the effect of spatial structure of citrus trees. In the same column, values followed by the same letter are not significantly different (Tukey's HSD test with $\mathrm{a}=0.05$ )

\begin{tabular}{ccc}
\hline & \multicolumn{2}{c}{ Severity of PLFSD } \\
\cline { 2 - 3 } Plots groups & Leaves & Fruits \\
\cline { 2 - 3 } ReSS plots & $19.04 \pm 22.04^{\mathrm{a}}$ & $14.97 \pm 8.49^{\mathrm{a}}$ \\
RaSS plots & $20.22 \pm 23.38^{\mathrm{ab}}$ & $16.32 \pm 14.32^{\mathrm{ab}}$ \\
Ag SSplots & $27.50 \pm 33.77^{\mathrm{c}}$ & $30.37 \pm 31.7^{\mathrm{c}}$ \\
Anova/Tukey-test & & 2 \\
Df & 2 & 11.2 \\
F value & 6.30 & $1.5 \mathrm{e}-05^{* * *}$ \\
Pr (>F) & $0.00189^{* *}$ & \\
\hline
\end{tabular}

ReSS: Regular Spatial Structure; RaSS: random Spatial Structure; AgSS: Aggregated Spatial Structure.

spatial structure are significantly more affected by the disease than those with citrus trees in a regular spatial structure. The three plots with Citrus trees in an aggregated spatial structure present a significantly higher mean of severity (28.55 on leaves, 30.37 on fruits) compared to the mean severity in the 7 plots with Citrus trees presenting a regular spatial pattern (16.28 on leaves, 14.97 on fruits; at $\mathrm{P}$-value $<0.05)$. The mean disease severity within the nine plots with a random spatial structure of Citrus trees (20.91 for leaves, 16.32 for fruits) tended to be higher to the mean of disease in the regular group and less than the mean in the aggregated group.

\subsection{Vegetation Composition in the Different Spatial Types}

The five subpopulations were present in the three spatial types, and the tendencies observed in terms of population composition are almost the same in the three types with small differences (Table 2). Results show that all the plots are basically cocoa plantations as they are composed of more than $85 \%$ of cocoa trees in each type. In two cases (random and regular), citrus is the second subpopulation in percentage, followed by forest and other fruit trees. Palm oil are not very representative. In the data set, we found that the percentage of citrus trees tends to be lower in the plots with an aggregated spatial organisation, but the trend was not significant between the three groups of spatial structure $(\mathrm{p}<$ $0.05)$.

\subsection{Citrus Composition and Sensibility in the Different Spatial Types}

A total of 438 citrus trees were observed in the 19 plots. In terms of species composition, the tendencies observed are almost the same. Orange trees represent more than $68 \%$ of citrus trees in all the spatial types, followed by tangerine, grapefruit and lemon trees respectively. There is no significant difference between citrus trees composition among the spatial types. 
Table 2. Percentage of cocoa trees, forest trees, fruit trees, citrus, and palm oil trees in cocoa based agroforest with aggregated, random, and regular spatial structure of citrus trees.

\begin{tabular}{cccccc}
\hline Spatial types & Cocoa trees & Forest trees & Others fruit trees & Citrus & Palm oil \\
\hline Aggregated & 89.80 & 2.29 & 3.98 & 3.66 & 0.27 \\
Random & 85.39 & 2.80 & 2.53 & 8.87 & 0.41 \\
Regular & 86.00 & 4.79 & 2.36 & 6.17 & 0.67 \\
\hline
\end{tabular}

\subsection{Geographical Zones of the Different Spatial Types}

Concerning zones localisation, regular plots are well distributed among the 3 zones (plot 2 and 6 from evergreen humid forest zone; plots 8, 10 and 14 from forest-savannah transition zone; plots 12 and 19 from degraded humid forest zone).

The random plots also belong to all the 3 zones (plot 1, 3 and 5 from Evergreen humid forest zone; plots 9, 11, 13 and 15 from Forest-savannah transition zone; plots 16 and 17 from Degraded humid forest zone). The aggregated plots also belong to all the three zones (plot 4 from Evergreen humid forest zone; plot 7 from Forest-savannah transition zone; plots 18 from Degraded humid forest zone). There is no significant influence of the geographical zone in the disease severity observed in the spatial types.

\section{Discussion}

In Cameroon, citrus trees are mostly grown in cocoa based agroforests, and PLFSD is one of the biggest constraints for their productivity and production. The aim of this paper was to identify the interaction between the spatial structure of citrus trees and the severity of PFLSD on the crop. This will lead to identify production systems that can contribute to control the negative impact of the PFLSD of citrus, and lead to the development of integrated pest management package delivery. Taking into account the pathogen physiology and its infection and dissemination factors, the creation of a microclimate or barriers against the propagation of the fungi may contribute to limit PFLSD development.

The spatial structure of the host trees of the studied disease was therefore assessed as the spatial structure of host individuals has an influence on the local environment around a host. This can have an impact on different mechanisms related to the dynamics and development of the hosted pathogens [4]. The present study revealed that one of such mechanisms is the creation of a micro-climate in the system by the maintenance or introduction of species of interest, which may act as barriers to inoculum propagation. The positive role of agroforestry systems in reducing the incidence of PLFSD compared to pure orchards has been shown [16]. However, there is a variability of such systems depending on environment and farmers' circumstances. It is therefore necessary to identify the spatial structure, which is less conducive to the spread of the disease.

Three types of spatial structures of citrus trees were found in the 19 studied 
plots. These different spatial structures were correlated to different PLFSD severity levels. The plots with Citrus trees in an aggregated spatial structure presented a significantly higher mean of severity on leaves and fruits, compared to the mean severity in the plots with a regular spatial structure.

The aggregated spatial structure was found in three plots. In these plots, Citrus trees formed aggregates of different sizes. As citrus trees are introduced, it is difficult to guess the origin of such aggregates, without a proper investigation on farmers' circumstances in these types of plots. From our knowledge and as farmers mentioned, the presence of inherited citrus trees in their farms can form aggregates (mother trees and regeneration). Other reasons such as bordering the farms with citrus trees, i.e. setting an important density of citrus trees in localised zones in the plot, which is also a common practice in these zones can lead to this mode of trees dispersion (as observed in plot 7).

These plots with an aggregated spatial pattern presented the highest disease severity. Conidia of $P$. angolensis are dispersed along short distances by wind and rain [15]. An aggregate distribution of trees promotes the dissemination of inoculum within a short distance. Moreover, previous studies [16] showed that the spatial pattern of diseased trees was aggregated in orchards. This corroborates the findings of [22], related to the spread of inoculums mostly due to rain splash, contrary to the case of citrus post bloom fruit drop, where this spatial pattern was random, meaning that inoculum spread was due to other mechanisms.

Thus, PLFSD is spread from one tree to its nearest neighbours according to the wind velocity and intensity of rain. The infection depends on the presence and quality of the host. In the case where the neighbours are susceptible hosts, the infection spreads and the epidemiological cycle continues. This mode of propagation favours disease spread within the aggregates and can therefore be seen as a small orchard within the agroforest plot. However, earlier study showed that beyond $12 \mathrm{~m}$ of distance between two neighbour trees, there is no more spatial dependence as far as disease spread is concerned [16], meaning that distance between neighbour trees is an important factor in disease dissemination.

The regular spatial structure was found in seven plots. This regular spatial structure can be attributed to the cultural techniques used to manage the plot (planting, thinning...). Indeed, citrus trees (like cocoa and other fruit trees) are trees introduced by farmers in cocoa agroforestry systems [18]. This can explain the regular spatial structure observed. The plots with a regular spatial pattern presented the lowest disease severity. This result is similar to that observed in the case of the spread of Phytophthora gummosis on citrus fruits in agroforestry systems [20]. However, as already said, the distance between 2 trees plays an important role in disease transmission, the longer the distance, difficult is the transmission [23]. In most regular plots, the mean distance between neighbour citrus trees is long $(>5 \mathrm{~m})$ and does not favour disease spread. Also the presence of many cocoa trees, forest or other fruit trees in-between neighbour citrus trees, 
may limit disease spread as they have a barrier effect, or create a microclimate modification as shown with other plant pathogens on coffee [24].

The random spatial structure was noticed in nine plots. As discussed in [4], who worked on spatial structure of shade trees (forest and fruit trees) in cocoa agroforestry systems, this random structure may be explained by the willingness of farmers to achieve a uniform shade of cocoa trees. Thus, depending on the existing distribution of native trees in the plot, fruit trees as citrus trees are planted to fill the vacancies in the plot, thereby producing shading for cocoa.

The introduction of citrus trees has 2 advantages for the farmer: maximize the production of fruit trees while creating shading for cacao development and production [25]. Therefore, the random distribution of citrus trees in the plot can be justified by these circumstances. However, the random spatial distribution may also be attributed to a statistical effect. As illustrated by [1], the null hypothesis of random distribution of a set of trees (here the citrus trees) cannot be rejected when the $L(\mathrm{r})$ function is within the confidence envelope. As the length of confidence envelope depends on the analysed tree density, the lower the density, the larger the confidence envelope. An $L(\mathrm{r})$ function within a confidence envelope can also be an effect of the low density of the analysed citrus trees. The disease severity is intermediate in this group, lower than in the aggregated group and greater than in the regular group. This can be explained by the fact that this structure is also intermediate between the first two structures.

In the study zones, an interesting effect of the spatial structure on the disease severity was highlighted. To interpret the effects of spatial pattern, we account for other potential differences in the plots within the same spatial type, which could underpin the highlighted effect. The other potential differences may come from factors known to influence the disease severity: Vegetation composition, Citrus composition and sensibility, and geographical zones with different altitudes and temperatures [13]. They were no significant difference in vegetation composition among the plots of the different spatial types. In addition, citrus composition and susceptibility was homogeneous among the plots of the different spatial types. Concerning the potential effect of the geographical zones, the three aggregated plots were found in each of the three selected geographical zones.

Previous works in cocoa agroforests in Cameroon and Costa Rica have already shown the impact of spatial structure of trees on cacao pests and diseases [1] [3] [4], and the effect of spatial structure of citrus on Phytophthora foot rot disease of citrus [20]. The spatial structure of trees at plot scale should definitely be considered as another factor influencing disease severity. Concerning the present study, it may be interesting to confirm the spatial structure effect experimentally. This could be made by designing experimentation with different spatial pattern of citrus trees, and by measuring the disease severity in experimental plots with an aggregated spatial structure of citrus trees, with aggregates of different sizes and with different distances between citrus trees. An aggregated spatial structure of citrus trees is correlated with the highest mean disease severity. Also, since no 
alternate host of $P$. angolensis has yet been found, the presence of other trees subpopulations in-between two neighbour citrus trees is also important, as they play a role of physical barriers and limit the transport of conidia from one citrus to the other. Thus, they permit reduction of disease spread at the scale of a plot in agroforestry systems.

\section{Conclusion}

This study was conducted to identify the interaction between the spatial structure of citrus trees in cocoa agroforestry systems and the PLFSD severity on citrus. Implications of obtained results in terms of ecological regulation of PLFSD in cocoa based agroforestry through the optimization of the spatial structure of citrus trees were discussed. An interesting and original effect of spatial structure of citrus trees on PFLSD of citrus was found in this work. Aggregated plots presented a significantly higher mean of disease severity as compared to randomised and regular plots. These results allow emphasizing that the spatial structure of citrus trees in the cocoa based agroforestry influences the severity of PFLSD. But, in this spatial structure effect, the notion of distance between neighbour trees has to be taken into consideration as the disease is easily spread within shorter distances in-between neighbour citrus trees. It will therefore be interesting to find a more important number of plots with aggregated spatial pattern of citrus trees, in order to confirm these results, and to characterise the management associated. This may help to suggest proper guidelines to avoid aggregated spatial pattern of citrus trees in cacao agroforests.

\section{Acknowledgements}

The Cameroon Institute of Agricultural Research for Development (IRAD); The Centre International de Recherche Agronomique pour le Développement (CIRAD); and "perennial Intercrop Diversity Tradeoffs in West and Central African cocoa farms (Tradeoffs in cocoa)" and "Enhancing food security and well-being of rural African Households through Improved synergy between Agroforestry Systems and Food crops." That funded this work;

\section{Conflicts of Interest}

The authors declare no conflicts of interest regarding the publication of this paper.

\section{References}

[1] Ngo Bieng, M.A., Gidoin, C., Avelino, J., Cilas, C., Deheuvels, O. and Wery, J. (2013) Diversity and Spatial Clustering of Shade Trees Affect Cacao Yield and Pathogen Pressure in Costa Rican Agroforests. Basic and Applied Ecology, 14, 329-336. https://doi.org/10.1016/j.baae.2013.03.003

[2] Calonnec, A., Burie, J. B., Langlais, M., Guyader, S., Saint-Jean, S., Sache, I. and Tivoli, B. (2013) Impacts of Plant Growth and Architecture on Pathogen Processes and Their Consequences for Epidemic Behaviour. European Journal of Plant Pathology, 135, 479-497. https://doi.org/10.1007/s10658-012-0111-5 
[3] Gidoin, C., Avelino, J., Deheuvels, O., Cilas, C. and Bieng, M.A.N. (2014) Shade Tree Spatial Structure and Pod Production Explain Frosty Pod Rot Intensity in Cacao Agroforests, Costa Rica. Phytopathology, 104, 275-281. https://doi.org/10.1094/PHYTO-07-13-0216-R

[4] Gidoin, C., Babin, R., Beilhe, L.B., Cilas, C., Hoopen, G.M.T. and Bieng, M.A.N. (2014) Tree Spatial Structure, Host Composition and Resource Availability Influence Mirid Density or Black Pod Prevalence in Cacao Agroforests in Cameroon. PLoS ONE, 9, e109405. https://doi.org/10.1371/journal.pone.0109405

[5] Kuate, J. (1998) Cercospora Leaf and Spot Disease of Citrus Caused by Phaeoramularia angolensis. Cahiers Agricultures, 7, 121-129.

[6] Brentu, F.C., Cornelius, E.W., Lawson, L.E.V., Oduro, K.A. and Vicent, A. (2013) First Report of Pseudocercospora angolensis Causing Fruit and Leaf Spot of Citrus in Ghana. Plant Disease, 97, 1661. https://doi.org/10.1094/PDIS-06-13-0615-PDN

[7] Yesuf, M. (2013) Pseudocercospora Leaf and Fruit Spot Disease of Citrus: Achievements and Challenges in the Citrus Industry. A Review. Agricultural Sciences, 4, 324-328 https://doi.org/10.4236/as.2013.47046

[8] Seif, A.A. and Hillocks, R.J. (1993) Phaeoramularia Fruit and Leaf Spot of Citrus with Special Reference to Kenya. International Journal of Pest Management, 39, 45-50. https://doi.org/10.1080/09670879309371757

[9] Kuate, J., Bella-Manga, F., Rey, J.Y. and Foure, E. (1994) Symptoms of Cercospora Leaf and Spot Disease on Citrus Due to Phaeoramularia angolensis. Fruits, 49, 31-36.

[10] Seif, A.A. and Hillocks, R.J. (1998) Some Factors Affecting Infection of Citrus by Phaeoramularia angolensis. Journal of Phytopathology, 146, 385-391.

[11] Kuate, J., Fouré, E., Foko, J., Ducelier, D. and Tchio, F. (2002) Citrus Phaeoramulariosis Due to Phaeoramularia angolensis in Cameroon: Parasitic Expression at Different Altitudes. Fruits, 57.

[12] Kuate, J., Jazet-Dongmo, P.M., Ducelier, D., Damesse, F., Menut, C. and Bessière, J.M. (2003) Effects of Cercospora to Phaeoramularia angolensis to the Content and the Chemical Composition of Essential Oils of Orange Peels. Fruits, 58, 143-149. https://doi.org/10.1051/fruits:2003002

[13] Ndo, E.G.D., Bella-Manga, F., Atanga Ndindeng, S., Ndoumbe-Nkeng, M., Ajong Dominic Fontem, A.D. and Cilas, C. (2010) Altitude, Tree Species and Soil Type Are the Main Factors Influencing the Severity of Phaeoramularia Leaf and Fruit Spot Disease of Citrus in the Humid Zones of Cameroon. European Journal of Plant Pathology, 128, 385-397. https://doi.org/10.1007/s10658-010-9660-7

[14] Bella-Manga., Dubois, C., Kuate, J., Mimbimi-Ngbwa, M. and Rey, J.Y. (1999) Sensibilité à Phaeoramularia angolensis de divers espèces d'agrumes cultivés en zone forestière humide du Cameroun. Fruits, 54, 167-176.

[15] Yesuf, M. (2002) Phaeoramularia Leaf and Fruit Spot of Citrus: A Major Threat to Citrus Production in Tropical Africa, Present Status and Future Perspectives. Paper presented at the Horticulture Seminar on Sustainable Horticultural Production in the tropics Jomo Kenyatta University of Agriculture Technology Juja Kenya.

[16] Ndo, E.G.D. (2011) Evaluation of Epidemiological Risk Factors of Phaeoramularia Leaf and Fruit Spot Disease of Citrus in Humid Zones of Cameroon. Centre International d'études supérieures en sciences agronomiques, Montpellier, $204 \mathrm{p}$.

[17] Mitchell, C.E., Tilman, D. and Groth, J.V. (2002) Effects of Grassland Plant Species Diversity, Abundance, and Composition on Foliar Fungal Disease. Ecology, 83, 1713-1726. https://doi.org/10.1890/0012-9658(2002)083[1713:EOGPSD]2.0.CO;2 
[18] Jagoret, P., Kwesseu, J., Messie, C.A., Michel, I. and Malézieux, E. (2014) Valeurs d'usage des ligneuxutilisés en agroforesterie: Les cacaoyères du Centre-Cameroun. Bois et Fforêts des Tropiques, 321.

[19] Kuate, J., Bella-Manga, Damesse, F., Kouodiekong, L., Ndindeng, S.A., David, O. and Parrot, L. (2006) Fruit Trees Cultivated in Family Farms in the Humid Zone of Cameroon: A Survey. Fruits, 61, 373-387. https://doi.org/10.1051/fruits:2006037

[20] Akoutou Mvondo, E., Ndo, E.G.D., Ngo Bieng, M.-A., Ambang, Z., Bella Manga, C.C., Tsouga Manga, M.L. and Bidzanga Nomo, L. (2017) Assessment of the Interaction between the Spatial Organization of Citrus Trees Populations in Cocoa Agroforests and Phytophthora Foot Rot Disease of Citrus Severity. AgroForestry Systems, $10 \mathrm{p}$.

[21] Ripley, B.D. (1977) Modelling Spatial Patterns. Journal of the Royal Statistical Society $B, 39,172-212$. https://doi.org/10.1111/j.2517-6161.1977.tb01615.x

[22] Silva-Junior, G.J., Spósito, M.B., Marin, D.R., Ribeiro-Junior, P.J. and Amorim, L. (2014) Spatiotemporal Characterization of Citrus Postbloom Fruit Drop in Brazil and Its Relationship to Pathogen Dispersal. Plant Pathology, 63, 519-529. https://doi.org/10.1111/ppa.12138

[23] Ratnadass, A., Fernandes, P., Avelino, J. and Habib, R. (2012) Plant Species Diversity for Sustainable Management of Crop Pests and Diseases in Agroecosystems: A Review. Agronomy for Sustainable Development, 32, 273-303. https://doi.org/10.1007/s13593-011-0022-4

[24] Mouen Bedimo, J.A., Dufour, B.P., Cilas, C. and Avelino, J. (2012) Effects of Shade Trees on Coffee Arabica Pests and Diseases. Cahiers Agriculture, 21, 89-97.

[25] Jagoret, P., Michel-Dounias, I. and Malezieux, E. (2011) Long-Term Dynamics of Cocoa Agroforests: A Case Study in Central Cameroon. Agroforestry Systems, 81, 267-278. 